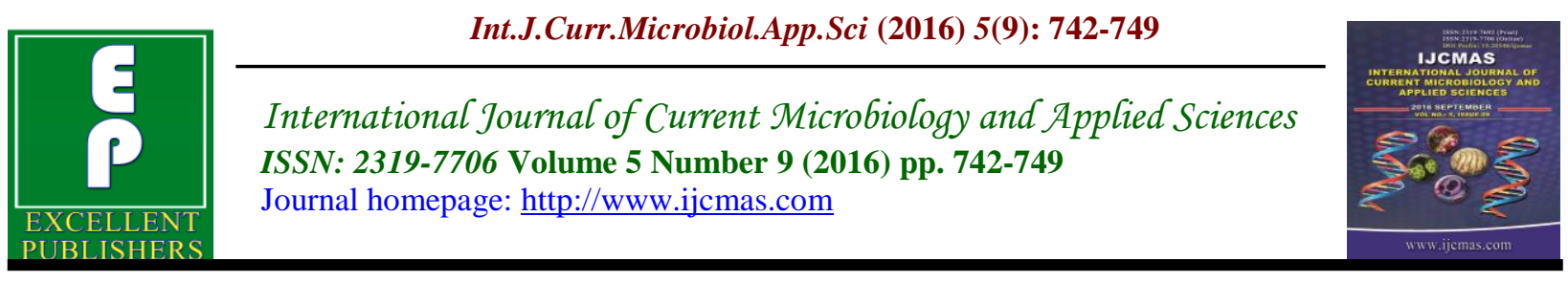

Original Research Article

http://dx.doi.org/10.20546/ijcmas.2016.509.085

\title{
Spectrophotometric Analysis of Degradation of Chlorpyrifos Pesticide by Indigenous Microorganisms Isolated from Affected Soil
}

\author{
Baby Sharma*, Sonika Saxena, Aparna Datta and Sudipti Arora \\ Dr. B. Lal Institute of Biotechnology, 6-E, Malviya Industrial Area, \\ Malviya Nagar, Jaipur-302017, India \\ *Corresponding author
}

\begin{tabular}{|c|c|}
\hline & A B S T R A C T \\
\hline $\begin{array}{l}\text { Pesticides, } \\
\text { Bioremediation, } \\
\text { Microorganisms, } \\
\text { Contamination. }\end{array}$ & \multirow{3}{*}{$\begin{array}{l}\text { In the present study, bacterial species were isolated from Chlorpyrifos } \\
\text { contaminated soils. These were identified as Bacillus and Micrococcus sp.. The } \\
\text { species were tested for their capabilities to degrade the pesticide at two different } \\
\text { concentrations }(0.05 \% \text { and } 0.1 \% \text { ) spectrophotometrically. After } 10 \text { days of } \\
\text { incubation maximum degradation of Chlorpyrifos was observed in Micrococcus sp. } \\
\text { with } 0.1 \% \text { of pesticide. Also physicochemical parameters of the contaminated soil } \\
\text { samples were tested and it was found that there was an increase in pH, Alkalinity, } \\
\text { Salinity, Phosphorus content and decrease in moisture content of the soil when } \\
\text { compared to the control soil that is unaffected by any pesticide, which proves the } \\
\text { ability of pesticides to deteriorate soil quality. Thus, these isolated bacterial species } \\
\text { could be used as potential candidates for bacterial mediated bioremediation of } \\
\text { pesticide. }\end{array}$} \\
\hline & \\
\hline $\begin{array}{l}\text { Accepted: } \\
28 \text { August } 2016 \\
\text { Available Online: } \\
\text { 10 September } 2016\end{array}$ & \\
\hline
\end{tabular}

\section{Introduction}

Pesticides are substances intended to prevent, destroy, repel, or mitigate pests. They are widespread environmental chemicals found in food, water, air, dust, and soil. These are xenobiotics that are recalcitrant in nature i.e. they remain in the environment for a very long time. The problem of environmental contamination by pesticides goes beyond the site where it is used. The agricultural pesticides that are exhaustively applied to land surface percolates down the groundwater and contaminate it. The recalcitrant nature of pesticide is also harmful to the environment since it hampers the fertility and productivity of the soil. It sometimes causes water body eutrophication by draining into lakes, ponds from the agricultural lands making water unfit for human consumption. Pesticide enters into the human body through the environment - soil, water, food, air and causes much harm to the human body (Ailabie et al., 1995).

Pesticides also harm the human health by entering into the food chain and hampering the reproductive capabilities of both male and female causing infertility problems as well as delayed conceptions and multiple miscarriages in females. It also causes damage to the CNS (central nervous system) and is also carcinogenic in nature. As these 
pesticides remains in the soil for a very long time the risk of exposure increases.

Chlorpyrifos belongs to organophosphorus category of pesticides. It is acutely toxic and their mode of action is by inhibiting acetylcholine esterase, an important enzyme in the nervous system. On exposure to these classes of pesticides, the enzyme is unable to work, thus causing accumulation of acetylcholine, which interferes with the transmission of the nerve impulse at the nerve ending. In humans it causes the following symptoms- general weakness, headache, salvation, nausea, vomiting, diarrhea, abdominal cramps and tumor. It also hampers the reproductive system of the humans (Singh et al., 2006)

Increase in the world population in turn has tremendously increased the need for the food which is the result of agricultural activities. Hence farmers have no scope to lose their produce due to pest attack as a result they are forced to use pesticides. These pest control chemicals are xenobiotic and persistent in nature and remain in the environment for a very long time. This results in soil pollution and loss of soil fertility. Pesticides not only affect the point where it is being applied but may flow far away into the water bodies carried away by the agricultural runoff and sometimes percolate down into the ground water or enter into food, produced by the plant through root absorption or can also spread in the air after its spray.

Through these channels pesticides enter into the human body and cause many harmful effects. Hence many studies have been conducted for the bioremediation of these xenobiotic through microbial agents which is an ecofriendly technique of cleaning up the environment. Thus the process of natural clean up by indigenous bacterial strains by bioremediation can be used for the degradation of chlorpyrifos from the affected soil (Atlas, 1988; Alexander et al., 1991).

Based on gaps identified, the present study is designed with the three main objectives. Firstly, to Isolate and identify pesticide degrading bacterial from pesticide contaminated soil. Second, assessment of the pesticide biodegradation potential from screened bacterial strains and Third, Degradation studies with different isolates at varying interval of time spectrophotometrically which will help to find out the most potent pesticide degrading strain.

\section{Material and Methodology}

\section{Collection of affected soil samples}

Collection of Chlorpyrifos affected soil samples was done by grab sampling technique from Rajasthan Agricultural Research Institute (RARI), Durgapura, Jaipur, Rajasthan. Along with it another soil sample which was not affected with any of the pesticides was taken as negative control for the study.

\section{Physico-chemical analysis of affected soil samples}

Soil is a complex mixture of organic and inorganic constituents. Major inorganic constituents of the soil include $\mathrm{Al}, \mathrm{Si}, \mathrm{Fe}$, $\mathrm{Mg}, \mathrm{Ca}, \mathrm{K}$ and $\mathrm{Na}$ and humus contributes to the physico-chemical parameters of the soil. For soil analysis the following physicochemical tests performed to determine the contamination in the chlorpyrifos affected soil pH, Alkalinity, Salinity, Moisture content, Sulphate, Phosphorus (Murugeasean et al., 2005). 


\section{Isolation of chlorpyrifos resistant bacteria}

The soil sample affected with chlorpyrifos was serially diluted and plated on nutrient agar amended with $0.1 \%$ of respective pesticides for the isolation and identification of bacteria resistant to Chlorpyrifos (Hindumathy et al., 2013).

\section{Identification of isolated bacteria}

For the identification of the bacterial strain microscopic and biochemical characterization techniques were being used. Simple staining and gram staining were initially done for microbial identification. Later for the confirmatory study, biochemical characterization tests such as IMViC test, Oxidase test, Catalase Test, Carbohydrate fermentation test, $\mathrm{NO}_{2}$ reduction testy were carried out (Cappuccino, 2001).

\section{Degradation study of Chlorpyrifos by isolated strains through spectrophotometric analysis}

When the microorganisms are inoculated in minimal salt medium which has no carbon source the microbes use alternative carbon source that is made available in the form of Chlorpyrifos which is being artificially embedded in the Minimal Salt Media (Sumit Kumar et al., 2011).

The pesticide degradation in the media was tested at a regular interval for 10 days by taking optical density of the cell free extract of the minimal media emended with chlorpyrifos at the absorbance maxima of chlorpyrifos i.e. 300nm (Vijay Kumar et al., 2015).

\section{Results and Discussion}

Bioremediation is found to be one of the most effective ways to get rid of the recalcitrant xenobiotics such as pesticides. Firstly, the present study was carried out to assess the quality of chlorpyrifos affected soil soils. The bacterial communities are believed to adapt to the local soil environment. These environmental factors play a vital role in the bioremediation of soil. All microorganisms need optimum $\mathrm{pH}$ and moisture for growth and functioning. Moisture also affects diffusion of water and soluble nutrients into and out of the microbial cells.

Table.1 Physico-chemical Parameters of chlorpyrifos affected soil

\begin{tabular}{|c|c|c|}
\hline Parameters & $\begin{array}{c}\text { Control } \\
\text { Soil sample }\end{array}$ & $\begin{array}{c}\text { Chlorpyrifos Affected Soil } \\
\text { Sample }\end{array}$ \\
\hline $\mathrm{pH}$ & 7.0 & 7.26 \\
\hline Moisture (\%) & 1.4 & 1.16 \\
\hline Alkalinity (meq./100g) & 0.15 & 0.55 \\
\hline Salinity (mg/100gm) & 13.44 & 14.20 \\
\hline Phosphorus content & 1.02 & 1.90 \\
\hline Sulphate content & Nil & Nil \\
\hline
\end{tabular}


Table.2 Biochemical Characterization of bacterial isolates

\begin{tabular}{|c|c|c|c|c|c|c|c|c|c|c|c|c|c|c|c|c|}
\hline \multirow{2}{*}{ Strains } & \multirow{2}{*}{$\begin{array}{l}\text { Gram } \\
\text { staining }\end{array}$} & \multirow[t]{2}{*}{ Indole } & \multirow[t]{2}{*}{ MR } & \multirow[t]{2}{*}{ VP } & \multirow[t]{2}{*}{ Citrate } & \multirow[t]{2}{*}{ Oxidase } & \multirow[t]{2}{*}{ Catalase } & \multirow{2}{*}{$\begin{array}{l}\mathrm{H}_{2} \mathrm{~S} \\
\text { productio } \\
\text { n }\end{array}$} & \multirow[t]{2}{*}{ Urease } & \multirow{2}{*}{$\begin{array}{l}\text { Starch } \\
\text { hydrolysi } \\
\text { s }\end{array}$} & \multirow[t]{2}{*}{ Gelatin } & \multirow{2}{*}{$\begin{array}{l}\mathrm{NO}_{2} \\
\text { reductio } \\
\text { n }\end{array}$} & \multicolumn{3}{|c|}{ Fermentation } & \multirow{2}{*}{$\begin{array}{l}\text { Micro-organism } \\
\text { Identified }\end{array}$} \\
\hline & & & & & & & & & & & & & $\mathbf{L}$ & G & $S$ & \\
\hline CLR1 & $\begin{array}{l}\text { Bacilli } \\
\text { GM+ }\end{array}$ & - & - & + & - & - & + & - & - & + & + & + & - & $\mathbf{A}$ & $\mathbf{A}$ & Bacillus sp. \\
\hline CLR2 & $\begin{array}{l}\text { Cocci } \\
\text { GM+ }\end{array}$ & - & - & - & - & - & + & - & + & - & + & + & - & - & - & $\begin{array}{l}\text { Micrococcus } \\
\text { sp. }\end{array}$ \\
\hline
\end{tabular}

Table.3 Spectrophotometric degradation assessment of Chlorpyrifos

\begin{tabular}{|c|c|c|c|c|c|c|c|c|}
\hline \multirow[t]{2}{*}{ Sample } & \multicolumn{4}{|c|}{$\begin{array}{l}\text { Strain } 1 \\
\text { Bacillus sp. }\end{array}$} & \multicolumn{4}{|c|}{$\begin{array}{l}\text { Strain } 2 \\
\text { Micrococcus sp. }\end{array}$} \\
\hline & $\begin{array}{l}0.05 \% \\
\text { chlorpyrifos } \\
\text { with } \\
\text { inoculation } \\
\text { (O.D) }\end{array}$ & $\begin{array}{l}0.05 \% \\
\text { Chlorpyrifos } \\
\text { control } \\
\text { (O.D) }\end{array}$ & $\begin{array}{l}0.1 \% \\
\text { Chlorpyrifos } \\
\text { with inoculation } \\
\text { (O.D) }\end{array}$ & $\begin{array}{l}0.1 \% \\
\text { Chlorpyrifos } \\
\text { control } \\
\text { (O.D) }\end{array}$ & $\begin{array}{l}0.05 \% \\
\text { Chlorpyrifos } \\
\text { with inoculation } \\
\text { (O.D) }\end{array}$ & $\begin{array}{l}0.05 \% \\
\text { Chlorpyrifos } \\
\text { control } \\
\text { (O.D) }\end{array}$ & $\begin{array}{l}0.1 \% \\
\text { Chlorpyrifos } \\
\text { with inoculation } \\
\text { (O.D) }\end{array}$ & $\begin{array}{l}0.1 \% \\
\text { Chlorpyrifos } \\
\text { control } \\
\text { (O.D) }\end{array}$ \\
\hline O DAY & 1.923 & 1.924 & 2.120 & 2.120 & 1.923 & 1.924 & 2.128 & 2.128 \\
\hline 2 DAY & 1.715 & 1.924 & 1.997 & 2.121 & 1.818 & 1.924 & 1.860 & 2.127 \\
\hline 4 DAY & 1.522 & 1.923 & 1.492 & 2.120 & 1.456 & 1.924 & 1.414 & 2.129 \\
\hline $6 \mathrm{DAY}$ & 1.352 & 1.924 & 1.351 & 2.120 & 1.427 & 1.924 & 0.975 & 2.128 \\
\hline 8 DAY & 0.315 & 1.924 & 1.333 & 2.120 & 1.071 & 1.924 & 0.652 & 2.128 \\
\hline 10 DAY & 1.074 & 1.924 & 1.286 & 2.120 & 1.039 & 1.924 & 0.607 & 2.128 \\
\hline
\end{tabular}


Table.4 Percentage Degradation of chlorpyrifos and residual pesticide analysis

\begin{tabular}{|l|l|l|l|l|}
\hline SAMPLE & \multicolumn{2}{|l|}{$\begin{array}{l}\text { Strain 1 } \\
\text { Bacillus } \boldsymbol{s} \text {. }\end{array}$} & $\begin{array}{l}\text { Strain 2 } \\
\text { Micrococcus } \boldsymbol{s} \text {. }\end{array}$ \\
\cline { 2 - 5 } & $\begin{array}{l}0.05 \% \\
\text { Chlorpyrifos } \\
(\mu \mathrm{l})\end{array}$ & $\begin{array}{l}0.1 \% \\
\text { Chlorpyrifos } \\
(\mu \mathrm{l})\end{array}$ & $\begin{array}{l}\text { 0.05\% } \\
\text { Chlorpyrifos } \\
(\mu \mathrm{l})\end{array}$ & $\begin{array}{l}\text { l } \\
\text { Chlorpyrifos } \\
(\mu \mathrm{l})\end{array}$ \\
\hline Control & 1.50 & 3.00 & 1.50 & 3.00 \\
\hline 0 Day & 1.50 & 3.00 & 1.50 & 3.00 \\
\hline 2 Day & 1.30 & 2.80 & 1.43 & 2.65 \\
\hline 4 Day & 1.16 & 2.10 & 1.10 & 1.92 \\
\hline 6 Day & 1.05 & 1.90 & 1.00 & 1.31 \\
\hline 8 Day & 1.02 & 1.82 & 0.83 & 0.95 \\
\hline 10 Day & 0.83 & 1.80 & 0.81 & 0.85 \\
\hline $\begin{array}{l}\text { \% } \\
\text { Degradation }\end{array}$ & $44 \%$ & $40 \%$ & $46 \%$ & $\mathbf{7 1 . 6 \%}$ \\
\hline
\end{tabular}

Fig.1 Sampling site Rajasthan Agriculture Research Institute, RARI, Jaipur, Rajasthan

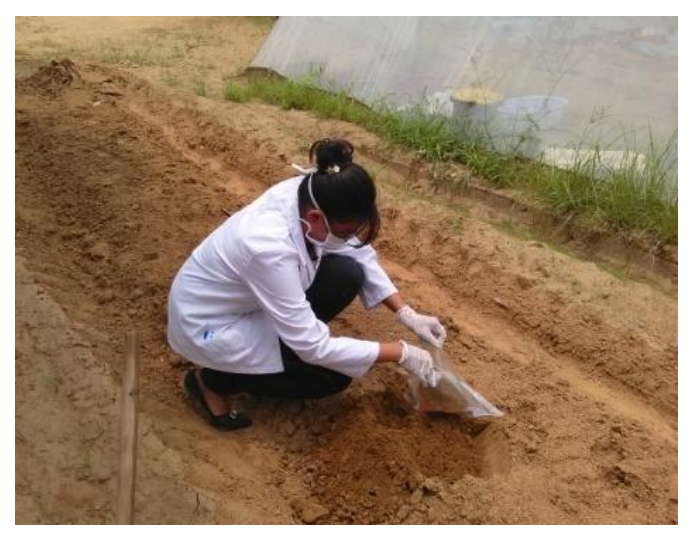

Fig.2 Pure colonies of isolated bacterial species on Nutrient Agar

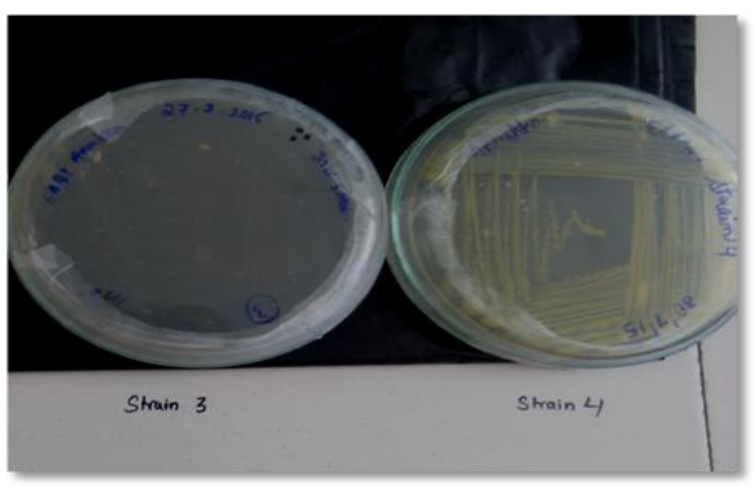


Fig.3 Gram Straining of Isolated bacterial stains

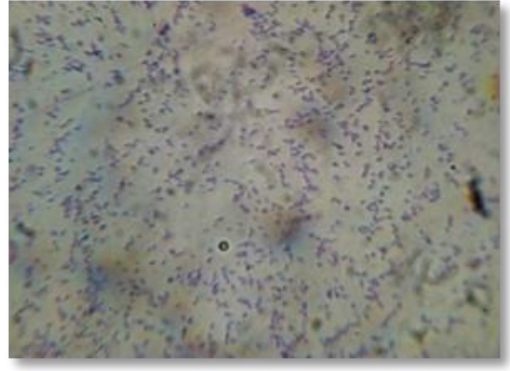

Fig 3a: Bacillus sp.

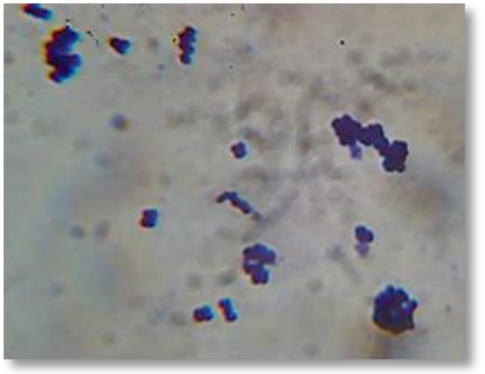

Fig 3b: Micrococcus sp.

Fig.4 Biochemical Tests for the isolates from pesticide contaminated soil

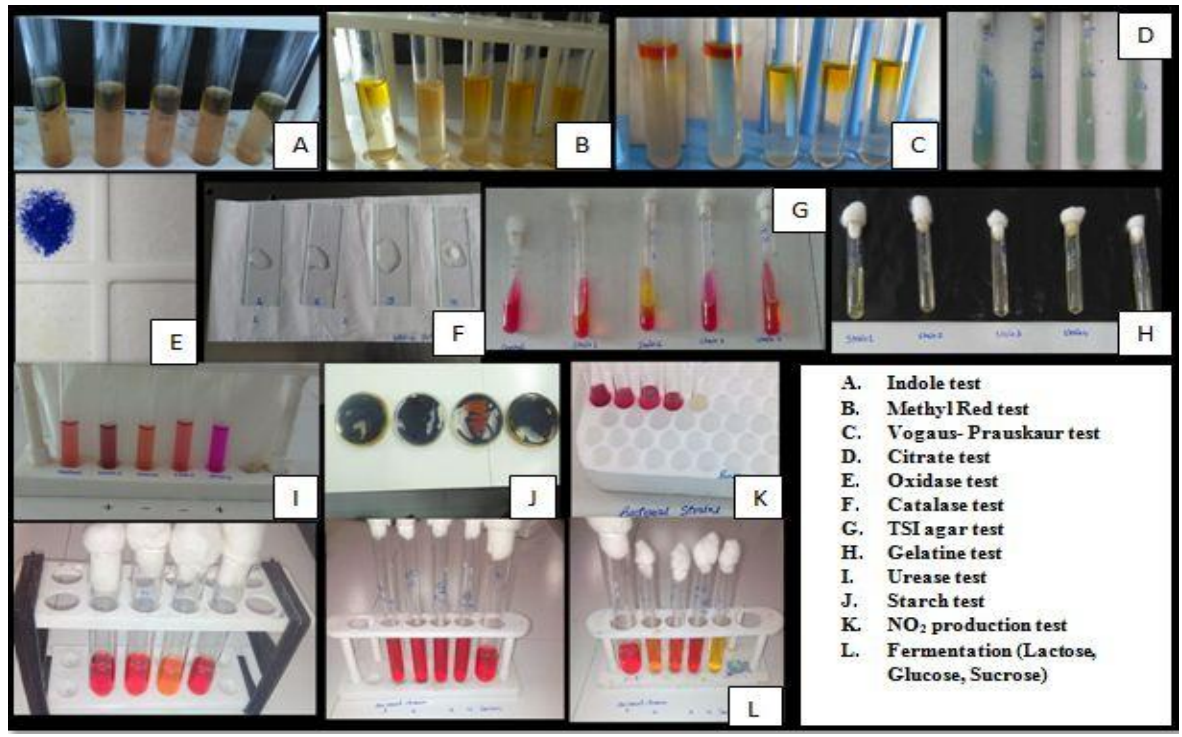

Graph.1 Comparative analysis chlorpyrifos degradation by the isolated strains

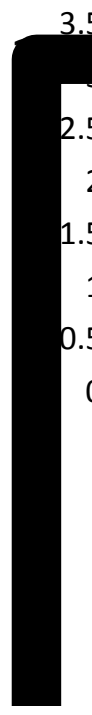

control

0 Day

2 Day

4 Day

6 Day

8 Day

10 Day

Time period (day)

$0.05 \%$ Chlorpyrifos Strain 3

0.05\% Chlorpyrifos Strain 4
$0.1 \%$ Chlorpyrifos Strain 3

$0.1 \%$ Chlorpyrifos Strain 4 
From the physico- chemical characterization of soil it is clear that there is an alteration in the quality of the chlorpyrifos affected soil (Table-1). A drastic change was noticed in the Phosphorus content of the pesticide affected soil which was higher than that of non contaminated soil sample which may be due to the fact that the pesticides used were of organophosphorus category (Zalat et al., 2014; Rosenberg et al., 1979).

Later, the isolation (Figure 2), morphological identification (Gram Staining) (Figure 3) and Biochemical identification tests (Figure 4) strains show that isolated Chlorpyrifos degrading microorganisms belonged to Bacillus sp. and Micrococcus sp.

In the spectrophotometric bioremediation study of the pesticide biodegradation data shows that the isolated Chlorpyrifos degrading microorganisms were Bacillus sp. \&Micrococcus sp. The Chlorpyrifos degrading Micrococcus sp. had shown the maximum degradation up to $71.6 \%$ when supplied with $0.1 \% \mathrm{v} / \mathrm{v}$ of Chlorpyrifos whereas the percent degradation was low $(46 \%)$ when supplied with $0.05 \% \mathrm{v} / \mathrm{v}$ of Chlorpyrifos after 10 days of incubation. In the case of Bacillus sp. the degradation of chlorpyrifos was as lower as $44 \%$ when $0.05 \% \mathrm{v} / \mathrm{v}$ chlorpyrifos was added which even lowered to $40 \%$ on supplying $0.1 \% \mathrm{v} / \mathrm{v}$ chlorpyrifos under similar incubation condition. The change in the biodegradation rate with change in the concentration of the pesticide is probably due to the fact that substrate availability is a key factor determining the rate of degradation of the pesticide by the bacterial agents (O'Conner, 1994). According to the review, the concentration of the pesticide must not be so high as to be toxic, nor so low that the bioremediation of the pesticide cannot proceed due to the lack of induction of appropriate degradative enzymes and uptake mechanisms or failure to induce sufficient enzyme activities (Mulbry et al., 1986; 1988).

In conclusion, pesticides are potent carcinogenic and toxic to human health as well as environment. Thus in the present study, Pesticide resistant bacteria genera were isolated and identified from the test soil samples contaminated with chlorpyrifos were Bacillus sp. and Micrococcus sp. It is therefore recommended that ability of the isolated and identified bacteria to bio remediate or utilize pesticide especially chlorpyrifos must be investigated. We found that maximum biodegradation of pesticide chlorpyrifos degradation was highest in Micrococcus sp. (71.6\%) when provided with $0.1 \%$ of the pesticide whereas minimum Chlorpyrifos degradation was seen in Bacillus sp. (40\%) with $0.1 \%$ of the pesticide determined by spectrophotometric analysis. We hereby suggest from the present investigations that diversity of indigenous microbes could be exploited using high throughput screening methods and the possible role of enzymes involved in the pesticide degradation are a further step to analyze the intricacies of the bioremediation activity. Thus, bioremediation techniques are more economical than traditional methods and pollutants can be treated on site. Other than that the risk of spread of contamination reduces making the process a safe one for dealing with very harmful xenobiotics like pesticides. Bioremediation is also very useful because the fertility of the soil that had been lost or hampered due to accumulation of pesticide for a very long period of time, thus improving the capacity of the agricultural field to meet the demands of the ever growing population efficiently (Lal et al., 1982). Thus, Bioremediation can be used to stabilize, detoxify, or reduce the toxicity of contaminated soil (Lewis et al., 1984). 


\section{References}

Aislabie, J. and Lloyd-Jones, G. 1995. A Review of Bacterial Degradation of Pesticides. Australian J. Soil Res., 33: 925-942.

Alexander, Aronstein, B.N. and Calvillo, Y.M. 1991. Effect of surfactants at low concentrations on the desorption and biodegradation of sorbed aromatic compounds in soil. Environ. Sci. Technol., 25: 1728-31.

Atlas, R.M. 1988. Microbiol. Fundamentals and Appli., 2nd Edition.

Hindumathy, Gayathri, V. 2013. Effect of Pesticide (Chlorpyrifos) on Soil Microbial Flora and Pesticide Degradation by Strains Isolated from Contaminated Soil. Bioremediation and Biodegradation, 4(2): 178- 1822.

James, G., Cappuccino. 2001. Microbiology Laboratory Manual. $7^{\text {th }}$ Edition.

Lal, R., Saxena D.M. 1982. Accumulation, Metabolism, and Effects of Organochlorine Insecticides on Microorganisms. Microbiol. Rev., 46: 95-127.

Lewis, D.L., Hodson, R.E. and Freeman, L.F. 1984. Effects of microbial community interactions on transformation rates of xenobiotic chemicals. Appl. Environ. Microbiol., 48: 561-565.

Mulbry, W.W. and Karns, J.S. 1988. Parathion hydrolase specified by the Flavobacterium opd gene: relationship between gene and protein. J. Bacteriol., 171: 6740-6.

Mulbry, W.W., Karns, J.S., Kearney, P.C., Nelson, J.O., McDaniel, C.S., and Wild, J.R. 1986. Identification of a plasmid-

\section{How to cite this article:}

Baby Sharma, Sonika Saxena, Aparna Datta and Sudipti Arora. 2016. Spectrophotometric Analysis of Degradation of Chlorpyrifos Pesticide by Indigenous Microorganisms Isolated from Affected Soil. Int.J.Curr.Microbiol.App.Sci. 5(9): 742-749.

doi: http://dx.doi.org/10.20546/ijcmas.2016.509.085 borne parathion hydrolase gene from Flavobacterium sp. by southern hybridization with opd from Pseudomonas diminuta. Appl. Environ. Microbiol., 51: 926-30.

Murugeasean, C., Rajakumari. 2005. Environmental Science and Biotechnology- Theory and Techniques. MJP Publishers.

O'Conner, B. 1994. Novachem Manual: A Guide to Plant Protection in New Zealand. Swift print: Palmerston North.

Rosenberg, Alexander, M. 1979. Microbial cleavage of various organohosphorus Insecticides. Appl. Environ. Microbiol., 37: 886-891.

Singh, B.K. and Walker. A. 2006. Bioremedial potential of fenamiphos and chlorpyrifos degrading isolatesInfluence of different environmental conditions. Soil Biol. Biochem., 38: 2682-2693.

Sumit Kumar. 2011. Bioremediation of chlorpyrifos by bacteria isolated from the cultivated soils. Int. J. Pharma and Bio Sci., 2(3): 359-366.

Vijay Kumar, Niraj Upadhyay, Virender Kumar, Sitansh Sharma. 2015. A Review on sample penetration and chromatographic determination of Acephate and Methamidophos in different sample. Arabian J. Chem., 8(5): 624-331.

Zalat, O.A., M.A. Elsayed, M.S. Fayed, M.K. Abd El Megid. 2014. Validation of UV Spectrophotometric and HPLC Methods for Quantitative determination of chlorpyrifos. Int. Lett. Chem. Physics and Astronomy, . 2: 58-63. 